AGRICULTURE AND BIOLOGY JOURNAL OF NORTH AMERICA

ISSN Print: 2151-7517, ISSN Online: 2151-7525, doi:10.5251/abjna.2011.2.12.1427.1436

(C) 2011, ScienceHuß, http://www.scihub.org/ABJNA

\title{
Effect of cowpea residue incorporation and nitrogen application rates on the productivity of upland rice
}

\author{
Okonji, C. J *1., Okeleye, K. A ${ }^{1}$, Aderibigbe, S.G'., Oyekanmi, A. A'., Sakariyawo, O. $\mathbf{S}^{1}$ \\ and Okelana, M.A.O ${ }^{2}$ \\ ${ }^{1}$ Dept of Plant Physiology and Crop Production University of Agriculture, Abeokuta. P.M.B \\ 2240. Ogun State \\ ${ }^{2}$ Dept of Horticulture University of Agriculture Abeokuta. P.M.B. 2240. Ogun State. \\ *Corresponding author (xokonji@gmail.com) \\ *. Present Address: College of Natural and Applied Sciences (CONAS), Department of \\ Biological Science \\ Crescent University Abeokuta, P.M.B 2104,Sapon, Abeokuta, Ogun State.
}

\begin{abstract}
A trial was conducted in 2009 and 2010 at the upland rice field of the Teaching and Research Farms of the University of Agriculture, Abeokuta (Latitude $7^{\circ} 2 \mathrm{~N}$ and $21^{\circ} \mathrm{E}$ ) to investigate effects of cowpea residue incorporation and nitrogen application rates on the productivity of upland rice. The experiment was laid out in Randomized Complete Block Design in split split plot arrangement and replicated three times. The main plot was cowpea incorporation at two levels (Residue incorporated and no cowpea residue incorporated), sub plot was nitrogen application rates $(0,20$, 40 and $60 \mathrm{Kg} \mathrm{N} \mathrm{ha}^{-1}$ ) while in the sub sub plots were the rice varieties (NERICA 2 and ITA 150). Results obtained were subjected to analysis of variance (ANOVA) and significant treatments means were separated using Least Significant Difference (LSD) method. The yield and yield components of rice measured were significantly $(P<0.01)$ influenced by the incorporated cowpea residue while nitrogen rates had significant $(P<0.01)$ influence on yield of rice in 2009 and 2010 . Rice varieties showed significant $(P<0.01)$ difference for all traits measured. It is concluded that the incorporation of grain cowpea with nitrogen fertilizer significantly $(P<0.01)$ enhanced the performance of upland NERICA rice.
\end{abstract}

Keywords:: Cowpea residue, nitrogen rates, rice, yield components and yield of rice.

\section{INTRODUCTION}

Rice is becoming increasingly important for food security in a number of low-income, food-deficit countries in Sub-Saharan Africa. The demand in SubSaharan Africa far outstrips production, which in the last 3 years has increased by $70 \%$ mainly because of the expanded area planted to rice. Only $30 \%$ of the increase can be attributed to improved productivity (Fagade, 2000). Upland rice accounts for about $44 \%$ of West Africa's total rice production. It is grown on about 1.3 million hectares (5\% of the total area under rice) primarily in Cote D'Ivoire, Guinea, Liberia, Nigeria and Sierra Leone. Over $70 \%$ of the region's peasant farmers grow upland rice as a subsistence crop. Yield varies considerably from 0.5 tonne/ha to 0.8 tonnes/ha (Abifarin et al., 1972). Slightly higher yields are obtained in areas where soil, rainfall and management conditions are favourable.
In an attempt to solve this problem, Africa Rice Centre (West Africa Rice Development Association WARDA) in the early 1990 s, initiated an inter-specific hybridization programme to improve rice productivity and yield potentials. The aim was to develop new low management rice plant types for resource limited, small holder production systems (Dingkuhn et al., 1998). The break through produced inter-specific rice cultivars from crosses between high yielding Asian rice (Oryza sativa L.) and low-yielding, resilient African rice (Oryza glabberima Stend.) These were named New Rice for Africa (NERICAs) and have enhanced upland rice production (FAO, 2007).

Recent studies on participatory varietal selection performed in Southern Western Nigeria on a wide range of upland rice cultivars (Asian rice, African rice and the NERICAs) showed that farmers preferred the NERICAs because of their good tillering ability and high tolerance to major biotic and abiotic stresses (Okeleye et al., 2006). 
Agric. Biol. J. N. Am., 2011, 2(12): 1427-1436

Recycling crop straw by application to the land can supply valuable quantities of plant nutrients and organic matter to meet crop nutrition requirement and maintain soil fertility (Prassad et. al. 2002). It was well documented that the incorporation of organic manure and crop straw into soil improves soil fertility and increases crop yield (Eneji et. al., 2001 Singh et. al, 2001). The use of poultry manure as it affects NERICA 1 improves its grain yield $\left(2.78\right.$ tha $^{-1}$, grains per panicle (191), panicle weight (32g), panicle length $(27 \mathrm{~cm})$, culm weight $(172 \mathrm{~g})$ and number of tillers (18) per hill (Oyekanmi et al., 2009). The adoption of legumes into rice-based cropping systems offers opportunities to increase and sustain productivity and income of smallholder farmers (Whitmore et al., 2000 and Wijnhoud et al., 2003). Incorporation of organic materials in the form of crop residues enhances the organic carbon level of the soil (Sarkar et. al.. 1988). $\mathrm{N}_{2}$-fixing legumes can have a positive impact on soil fertility by enhancing nitrogen availability and therefore benefiting a cereal crop grown in the subsequent season (Armstrong et al., 1999 and Sanginga, 2003).

As the application of organic manures brings about structural improvement, it increases air capacity, may cause the roots to extend into and exploit a larger volume of soil in addition to increasing water retention in the soil profile (Sarkar. et al., 2003., Pernes- Debuyser and Tessier, 2004). For example McDonagh et al. (1995) showed that $\mathrm{N}$ accumulation in pre-rice legumes ranged from 75 to $102 \mathrm{~kg} \mathrm{~N} \mathrm{ha}^{-1}$ resulting in an average $2 \mathrm{Mg} \mathrm{ha}^{-1}$ increase of rice yield compared to rice grown after a bare fallow control.

Thus, the importance of organic matter in relation to the physical fertility of the soil has been widely recognized (Barzegar. et al., 2002).

Justification : One of the major problems involved in the production of upland rice varieties in the forest savannah transition zone of Nigeria is the cost of acquiring inorganic fertilizer to boost the yield in rice production. The incorporation of legume residues in rice production is known to have improved the nutrient content of the soil, as well as its physical and chemical properties thereby minimizing cost and reducing dependence on inorganic fertilizers by farmers. Several studies have shown that some legumes can grow well before rice, producing large amounts of residues and fixing atmospheric $\mathrm{N}_{2}$, leading to considerable increase in yields of succeeding rice crops (McDonagh et al., 1995, Toomsan et al., 1995 and Toomsan et al., 2000).
Farmers in Nigeria, however, will usually adopt agrotechniques from which they can derive optimum direct financial benefits. The use of grain legumes e.g. cowpea, therefore, could be of a great benefit. The objective of this study was, thus, to assess the impact of addition of cowpea residues and nitrogen application rates on growth performance, yield and yield components of succeeding NERICA rice varieties,

\section{MATERIALS AND METHODS}

Location and site characterization: The experiment was conducted during the early planting seasons of 2009 and 2010 at the Teaching and Research farm of the University of Agriculture, Abeokuta (UNAAB) (Latitude $7^{\circ} 2 \mathrm{~N}$ and $21^{\circ} \mathrm{E}$ ). The experimental site had been cultivated to cowpea since 2004. After each year cultivation, the field is left uncultivated until the next season when cowpea is planted again on the same plot. Fields cultivated are marked to keep proper track of plots for next trial. Core soil samples were taken randomly for routine soil analysis for $\mathrm{pH}$, organic carbon, organic matter, exchangeable acidity, total nitrogen, available phosphorus, exchangeable bases, and particle size/texture.

Experimental design and treatments: The trial was laid out in a split- split plot arrangement in randomised complete block design (RCBD) with three replications. Incorporated cowpea residue and no cowpea residue incorporated were in the main plot, in the sub plot were the nitrogen rates $(0,20$, 40 and $60 \mathrm{Kg} \mathrm{N} \mathrm{ha}^{-1}$ ) while in the sub sub plot were the rice varieties (NERICA 2 and ITA 150). The total experimental area used was $1224 \mathrm{~m}^{2}$. Each replicate consisted of twelve plots of $5 \mathrm{~m}$ long and $4 \mathrm{~m}$ wide $\left(20 \mathrm{~m}^{2}\right)$. Each sub-sub plot consisted of 21 rows of rice planted at $20 \mathrm{~cm} \times 20 \mathrm{~cm}$. Each sub plot was separated by $0.5 \mathrm{~m}$ alley. Net plot size was $6 \mathrm{~m}^{2}$ of the plot area. Minimum tillage method which involves the application of a post emergence herbicide was employed for weeds removal. After two weeks the dead weeds and grain cowpea residues on plots were incorporated into the soil and left for another two weeks to decompose. Planting was done by dibbling in rows at $20 \mathrm{~cm} \times 20 \mathrm{~cm}$ with $4-5$ seeds per hole. Nitrogen was applied at the rates of 0, 20, 40 and $60 \mathrm{KgN} / \mathrm{ha}$. NPK 20-10-10 was used to supply $10 \mathrm{Kg} \mathrm{N} / \mathrm{ha}, 10 \mathrm{Kg} \mathrm{P} / \mathrm{ha}$ and $10 \mathrm{Kg} \mathrm{K} / \mathrm{ha}$ while the remaining $\mathrm{N}$ fertilizer requirement was sourced from Urea $(46 \% \mathrm{~N})$. Post planting activities consisted of manual weeding, pest control (rats and weaver birds) and harvesting. 


\section{Plant sampling and measurements.}

The following data were collected.

Days to $\mathbf{5 0} \%$ flowering: Number of days from planting to when half of the plant population in each plot has flowered.

Days to $95 \%$ maturity: Number of days from planting to when $95 \%$ grains from panicles of the plants in each plots had turned to brown in colour.

Grains per panicle: This was done by counting the number of grains on ten randomly selected panicles from the net plot and the average was then determined.

Panicle length: Ten panicles were selected randomly from the net plot, measured with ruler from the last node of the panicle to tip of the tallest grain on the panicle and the average was determined.

One thousand grain weight: This was determined by counting one thousand seeds from the net plot harvest and weighed.

Harvest index: Ratio of the weight of grains to the above ground plant weight expressed in percentage.

Panicle weight: Ten randomly selected panicles from the net plot were weighed and the average was determined.
Grain Yield: Grain yield harvested from net plot measuring $6 \mathrm{~m}^{2}$ was threshed and weighed. The weight was later converted to $\mathrm{kg} / \mathrm{ha}$.

\section{RESULT}

Plant height and dry matter of rice: The incorporation of cowpea residue had significant influence on plant height in both years at vegetative and maturity stages of rice grown (Table 1) compared to when cowpea was not incorporaed. In 2010 nitrogen rates at $60 \mathrm{~kg} \mathrm{~N} \mathrm{ha}^{-1}$ significantly influenced the height of rice at seedling $(25.7 \mathrm{~cm})$, vegetative $(66.7 \mathrm{~cm})$ and maturity $(98.1 \mathrm{~cm})$. Among the rice varieties ITA 150 had significantly taller plant height than NERICA 2. Incorporated cowpea residue $\times$ nitrogen had significant increased on plant height at the three stages of growth (Fig $1 \mathrm{a}, \mathrm{b}$ and $\mathrm{c}$ ). Incorporated cowpea residue $\times 60 \mathrm{~kg} \mathrm{~N}^{-1}$ also significantly increased the plant height of rice at seedling $(28.1 \mathrm{~cm})$, vegetative $(81.1 \mathrm{~cm})$ and maturity $(115.7 \mathrm{~cm})$. The rice varieties $\times$ incorporated cowpea residue significantly increased the plant height of rice as ITA 150 significantly had higher plant height at seedling $(27.7 \mathrm{~cm})$ and maturity $(110.2 \mathrm{~cm})$ compared to NERICA 2 (Fig $2 a$ and $b$ ).

Table 1: Mean effects of nitrogen source on plant height and dry matter of rice

\begin{tabular}{|c|c|c|c|c|c|c|c|c|}
\hline Treatment & \multicolumn{6}{|c|}{ Plant height (cm) } & \multicolumn{2}{|c|}{$\begin{array}{c}\text { Dry matter at } \\
\text { maturity }\end{array}$} \\
\hline & \multicolumn{3}{|c|}{2009} & \multicolumn{3}{|c|}{2010} & 2009 & 2010 \\
\hline Source & Seedling & Vegetative & Maturity & Seedling & Vegetative & Maturity & & \\
\hline $\begin{array}{l}\text { Cowpea } \\
\text { residue } \\
\text { incorporated }\end{array}$ & 35.5 & $75.3 a$ & $81.2 \mathrm{a}$ & 26.0 & $73.4 \mathrm{a}$ & $109.6 a$ & 18.4 & $30.1 \mathrm{a}$ \\
\hline $\begin{array}{l}\text { No Cowpea } \\
\text { residue } \\
\text { incorporated }\end{array}$ & 32.4 & $69.6 b$ & 73.0b & 22.9 & $50.3 b$ & $78.8 b$ & 18.2 & $20.7 b$ \\
\hline LSD (5\%) & ns & 1.2 & 2.0 & ns & 2.7 & 5.4 & ns & 4.7 \\
\hline \multicolumn{9}{|l|}{$\begin{array}{l}\text { Nitrogen rates } \\
\mathrm{kg} \mathrm{ha}^{-1}\end{array}$} \\
\hline 0 & 34.1 & 71.5 & 75.5 & $23.1 \mathrm{c}$ & $59.3 b$ & $91.9 c$ & $13.1 b$ & $18.5 d$ \\
\hline 20 & 32.9 & 71.5 & 75.6 & $24.5 b$ & $59.9 b$ & $93.5 b$ & $23.5 a$ & $24.5 c$ \\
\hline 40 & 34.5 & 72.7 & 78.5 & $24.6 b$ & $61.7 \mathrm{~b}$ & $93.4 b$ & $21.3 a$ & $28.3 b$ \\
\hline 60 & 34.3 & 73.9 & 79.1 & $25.7 a$ & $66.7 a$ & $98.1 \mathrm{a}$ & $15.2 b$ & $30.3 a$ \\
\hline LSD (5\%) & ns & ns & ns & 0.6 & 4.2 & 1.5 & 4.8 & 1.4 \\
\hline \multicolumn{9}{|l|}{ Rice varieties } \\
\hline ITA 150 & $41.7 a$ & 78.8 & $83.4 a$ & $25.9 a$ & $63.6 a$ & $95.6 a$ & $22.4 a$ & 25.9 \\
\hline NERICA 2 & $26.2 b$ & 66.0 & $70.9 b$ & $22.1 b$ & $57.6 \mathrm{~b}$ & $89.3 b$ & $14.1 \mathrm{~b}$ & 25.7 \\
\hline LSD (5\%) & 8.0 & $\mathrm{~ns}$ & 12.7 & 1.3 & 4.9 & 2.3 & 5.6 & $\mathrm{~ns}$ \\
\hline
\end{tabular}

The incorporation of cowpea residue had no significant influence on rice dry matter in 2009, while in 2010, incorporated cowpea residue significantly increased the dry matter of rice $(30.1 \mathrm{~g})$ at maturity as rice varieties showed no significant influence (Table 1). Nevertheless, nitrogen rates significantly influenced the dry matter of rice in 2010, as $60 \mathrm{~kg} \mathrm{~N} \mathrm{ha}^{-1}$ had the highest dry matter 
weight $(30.3 \mathrm{~g})$, while $0 \mathrm{~kg} \mathrm{~N}^{-1}$ had the lest weight $(18.5 \mathrm{~g})$.

Yield and yield component: The incorporation of cowpea residue significantly influenced the 1000 grain weight $(42.9 \mathrm{~g})$, number of grains per panicle (126) and yield (2.5 ton ha $\left.{ }^{-1}\right)$ of rice in 2009 , while in 2010 it also significantly increased panicle length $(26.4 \mathrm{~cm})$ and yield $\left(2.6\right.$ ton $\left.\mathrm{ha}^{-1}\right)$ of rice (Table 2).

The different $\mathrm{N}$ rates used showed no significant influence on the yield components measured in 2009 except for rice yield, where $60 \mathrm{~kg} \mathrm{~N}^{-1}$ significantly produced the highest grain yield $(2.7$ ton ha ${ }^{-1}$ ) compared to $0 \mathrm{~kg} \mathrm{~N} \mathrm{ha}^{-1}$. In 2010 trial $\mathrm{N}$ rates had significant influence on the yield and yield components of rice. It was observed that 60 and 40 $\mathrm{kg} \mathrm{N}$ ha $^{-1}$ significantly increased the number of grains per panicle of rice while panicle length (24.9, 25.2 and 25.3 at seedling, vegetative and maturity respectively) showed no significant difference between 60, 40 and $20 \mathrm{~kg} \mathrm{~N}^{-1}$ though significantly lower than $0 \mathrm{~kg} \mathrm{~N} \mathrm{ha}^{-1}$. The grain yield of rice was also significantly increased by $N$ rates as 40 and $20 \mathrm{~kg} \mathrm{~N} \mathrm{ha}^{-1}$ gave the highest grain yield (2.9 and 2.1 ton $\mathrm{ha}^{-1}$ ) although there was no significant difference between the yield of 60 and 40 $\mathrm{kg} \mathrm{ha}^{-1}$ (Table 2).

Among the rice varieties no significant difference was observed on the traits measured except for yield in 2009, where NERICA 2 significantly had the highest (2.3 ton ha ${ }^{-1}$ ) grain yield. In 2010, no significant difference was observed among the rice varieties except at grain yield and panicle length as NERICA 2 significantly had better performance.

Interaction effects on yield and yield components: In $200960 \mathrm{~kg} \mathrm{~N}$ ha $^{-1}$ with incorporated cowpea residue had the highest (150) number of grains per panicle as $40 \mathrm{~N} \mathrm{~kg} \mathrm{ha}{ }^{-1}$ with no cowpea residue had the lowest number of grains (114) per panicle (Table 3). In 2010, incorporation of cowpea residue $\times 60 \mathrm{~kg} \mathrm{~N}^{-1}$ significantly had the highest number of grains (130) per panicle as fields without cowpea residue $\times 0$ and $20 \mathrm{~kg} \mathrm{~N} \mathrm{ha}^{-1}$ had the lowest (81) number of grains per panicle (Table 3). The panicle length of rice was also significantly influenced by the interaction effect of incorporated cowpea residue $\times$ nitrogen rates as cowpea residue incorporated $x 40$ and $60 \mathrm{~kg} \mathrm{~N} \mathrm{ha}^{-1}$ in 2010 significantly increased the panicle length of rice (27.6 and $28.4 \mathrm{~cm}$ respectively), while fields without cowpea residue $\times 60 \mathrm{~kg} \mathrm{~N} \mathrm{ha}^{-1}$ had the lowest (21.4) panicle length (Table 3).
The interaction of rice $\times$ nitrogen rates on number of grain per panicle in 2009 was observed to be significant as $60 \mathrm{~kg} \mathrm{~N}^{-1}$ significantly influenced the number of grains per panicle (146) of ITA 150 and (143) of NERICA 2 while interaction of $0 \mathrm{~kg} \mathrm{~N}$ $\mathrm{ha}^{-1}$ with ITA 150 had the lowest (Fig 3a) number of grains per panicle (115). The panicle length of rice was also significantly influenced by the interaction effect of rice varieties $\times$ nitrogen rates in both years. In 2009 at $60 \mathrm{~kg} \mathrm{~N}^{-1}$ NERICA 2 significantly had the longest panicle length $(24.9 \mathrm{~cm})$, while in 2010 at 40 and $20 \mathrm{~kg} \mathrm{~N}^{-1}$ NERICA 2 also significantly had the longest panicle length of 25.8 and $25.5 \mathrm{~cm}$ respectively (Fig $3 \mathrm{~b}$ and $\mathrm{c}$ ).

The grain yield of rice was also significantly influenced by the interaction effects in 2010 as the interaction effect of rice varieties $x$ incorporated cowpea residue on yield showed that the two rice varieties ITA 150 (2.7 ton ha $^{-1}$ ) and NERICA 2 (2.1 ton $\mathrm{ha}^{-1}$ ) had better performance when planted in incorporated cowpea residue fields (Fig 4a). The interaction of nitrogen rates $x$ incorporated cowpea residue on yield also shows that with as little as 20 $\mathrm{kg} \mathrm{N} \mathrm{ha}^{-1}$ on incorporated cowpea residue fields a yield of 3 ton ha ${ }^{-1}$ was observed while fields without incorporated cowpea residue with a higher dose of nitrogen at $60 \mathrm{~kg} \mathrm{~N} \mathrm{ha}^{-1}$ gave a yield of 3.1 ton ha ${ }^{-1}$ which was not significantly different from the yield of rice with $20 \mathrm{~kg} \mathrm{ha}^{-1}$ with incorporated cowpea residue. (Fig 4b). Also the interaction effects of rice $x$ nitrogen rates on the yield of rice showed that the rice varieties responded significantly to the nitrogen rates (Fig 4c).

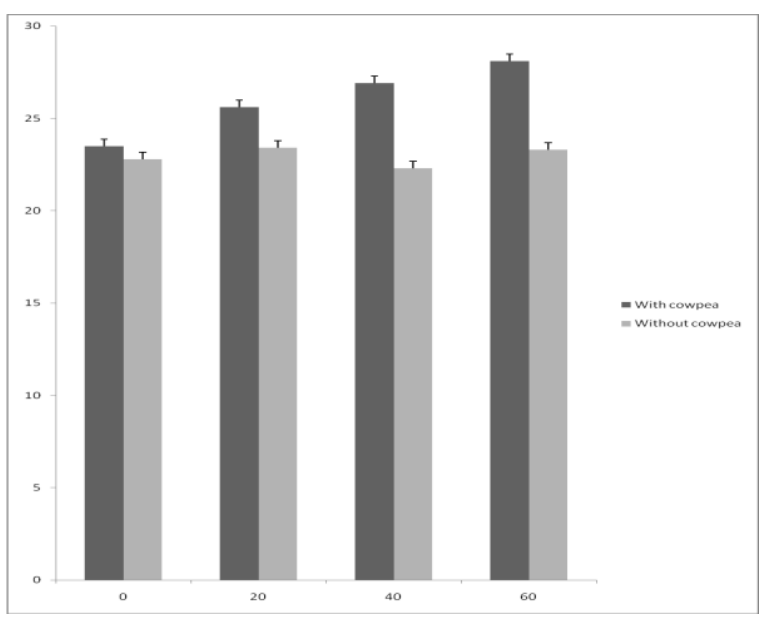

Fig 1a: Interaction effect of cowpea incorporation $x$ nitrogen rates at seedling in $\mathbf{2 0 1 0}$ 
Agric. Biol. J. N. Am., 2011, 2(12): 1427-1436

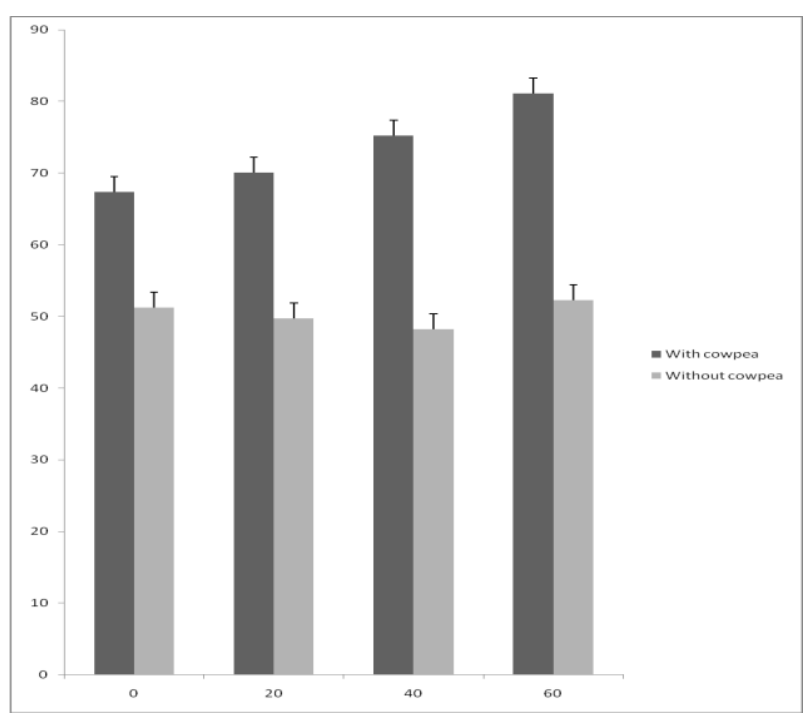

Fig 1b: Interaction effect of cowpea incorporation $x$ nitrogen rates at vegetative of rice in $\mathbf{2 0 1 0}$

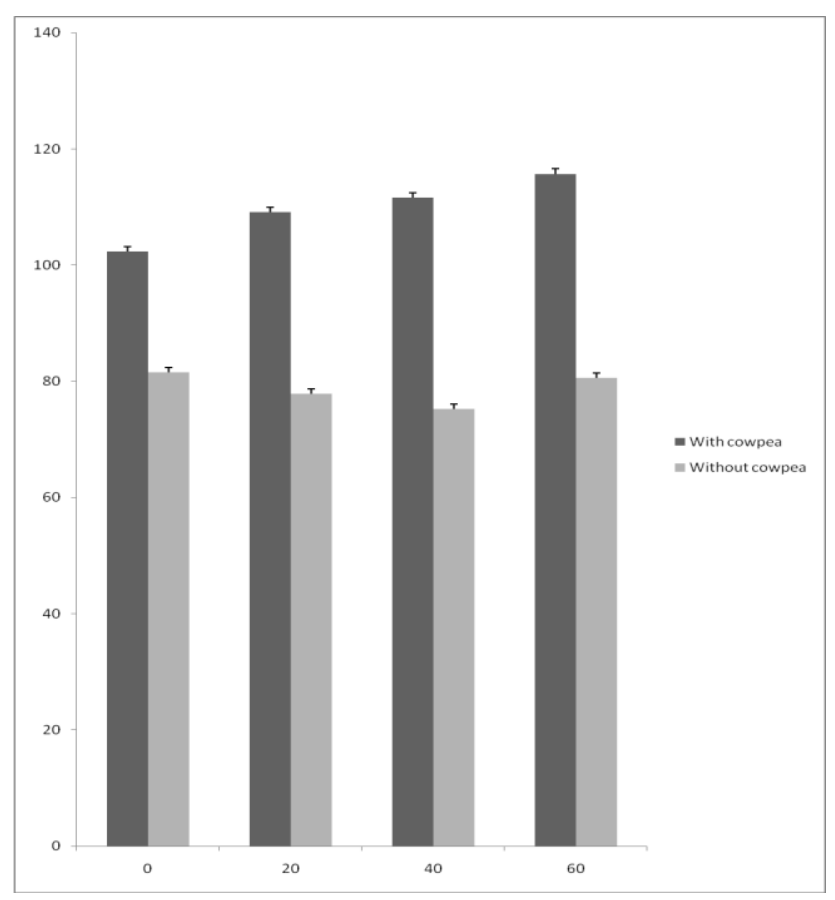

Fig 1c: Interaction effect of cowpea incorporation $x$ nitrogen rates at maturity of rice in $\mathbf{2 0 1 0}$

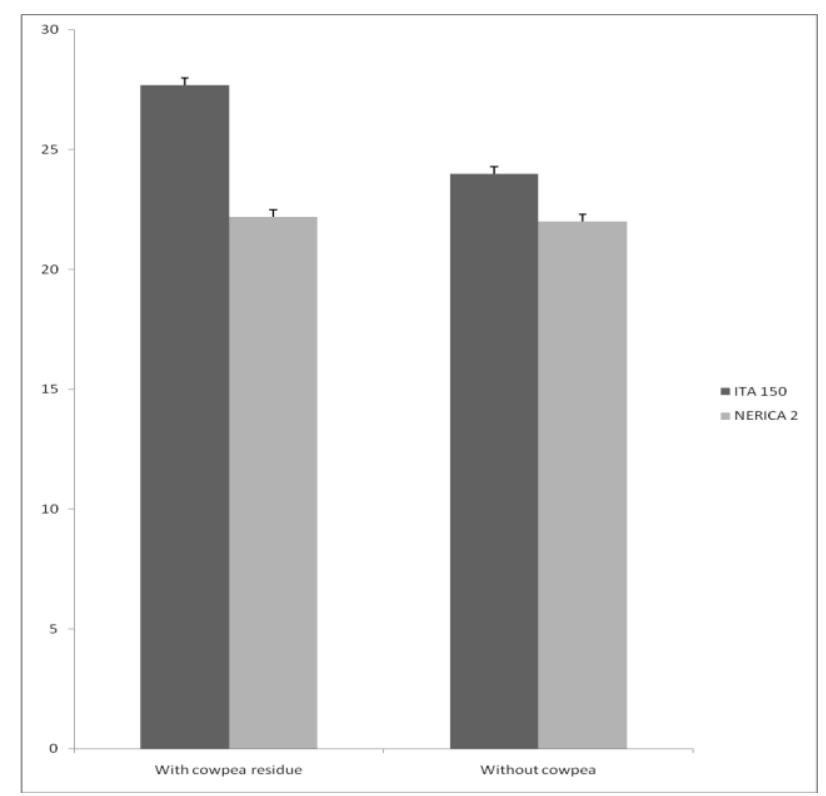

Fig 2a: Interaction effect of rice varieties $x$ cowpea incorporation on plant height at seedling in $\mathbf{2 0 1 0}$

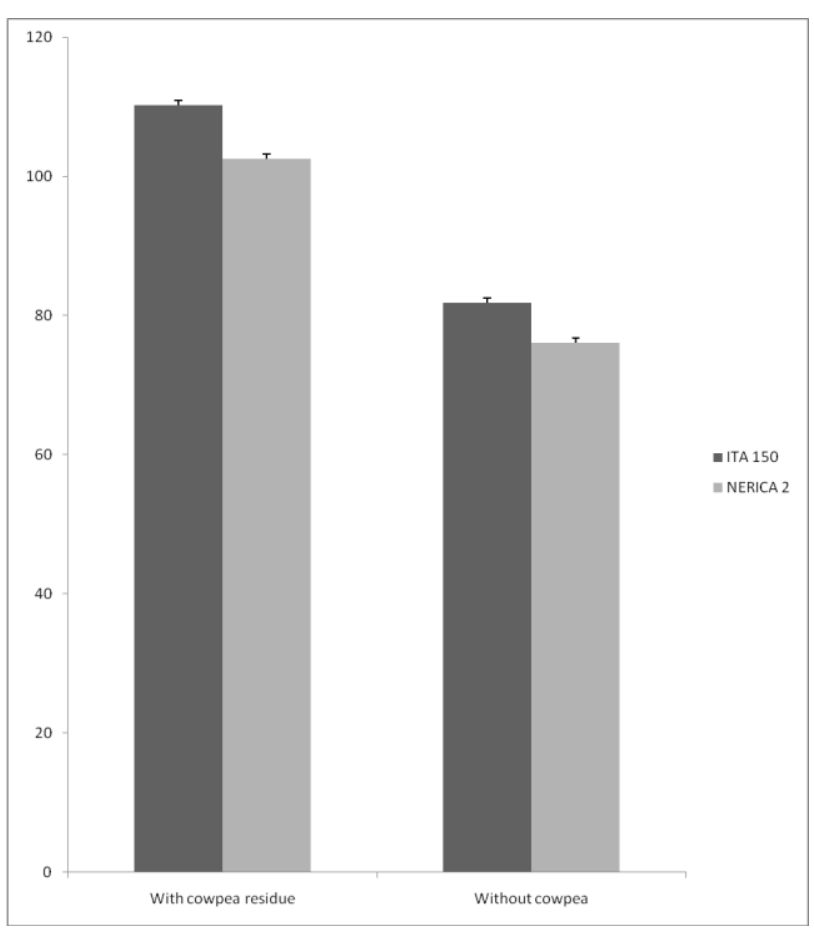

Fig 2b: Interaction effect of rice varieties $x$ cowpea incorporation on plant height at maturity in 2010. 
Agric. Biol. J. N. Am., 2011, 2(12): 1427-1436

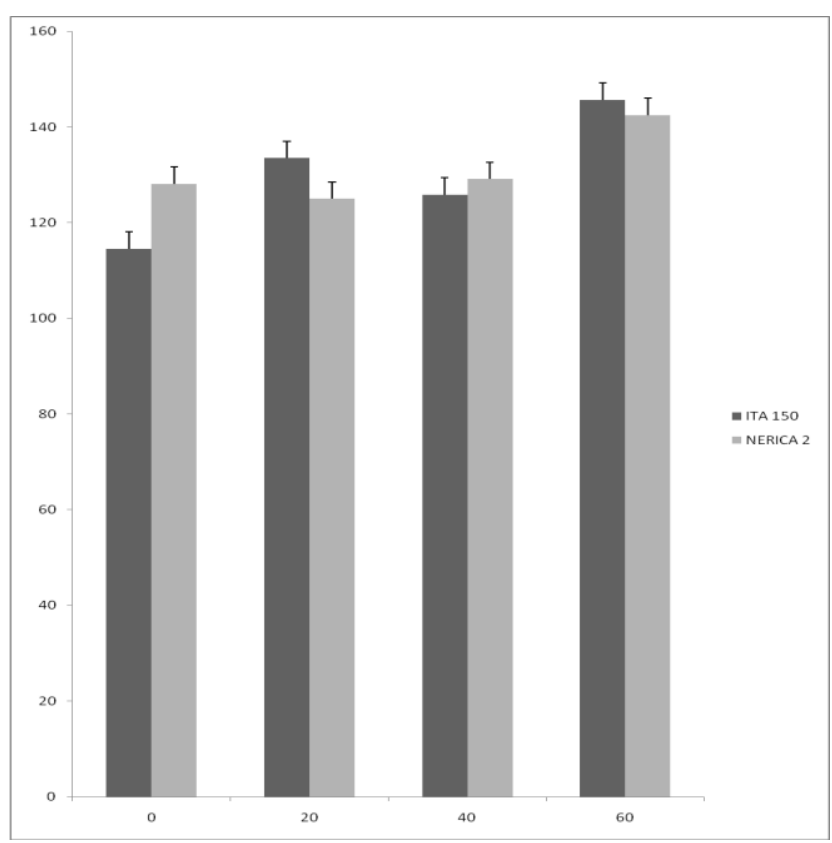

Fig 3a: Interaction effect of rice $x$ nitrogen rates on number of grains per panicle in 2009

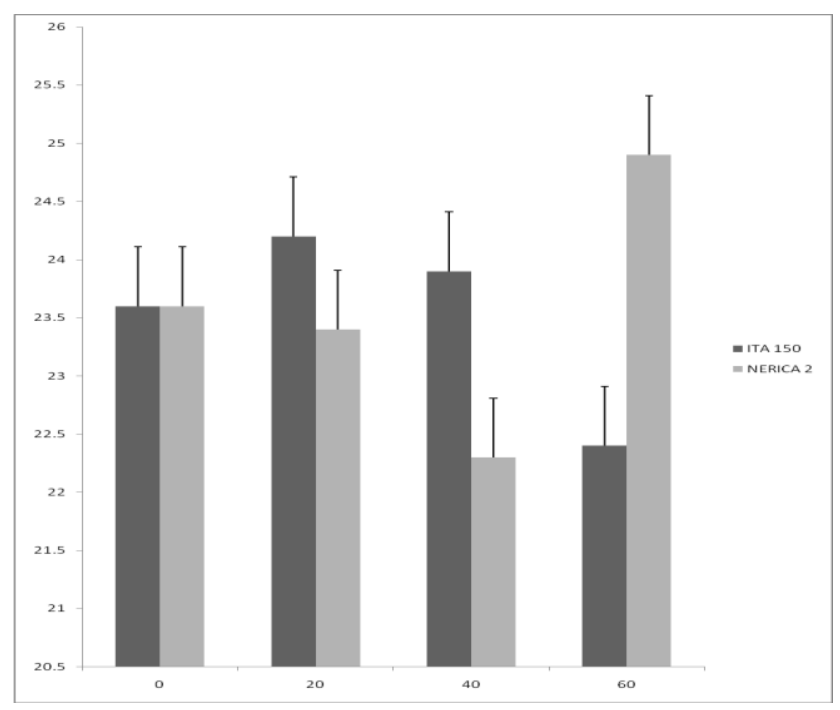

Fig 3b: Interaction effect of rice $\mathrm{x}$ nitrogen rates on panicle length of rice in 2009

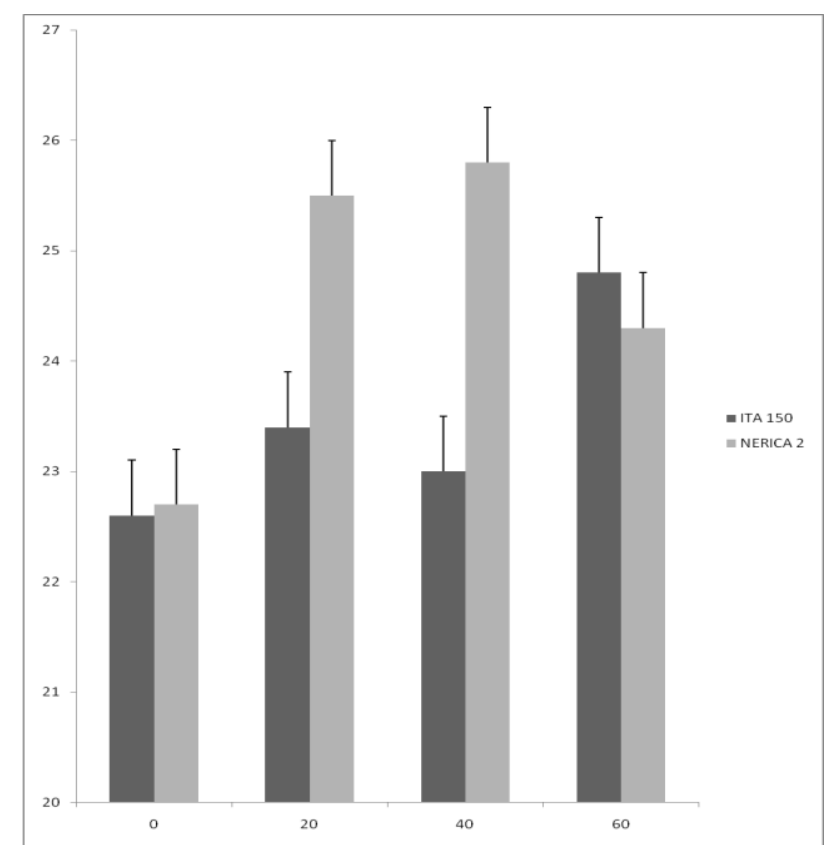

Fig 3c: interaction effect of rice $x$ nitrogen rates on panicle length of rice in $\mathbf{2 0 1 0}$

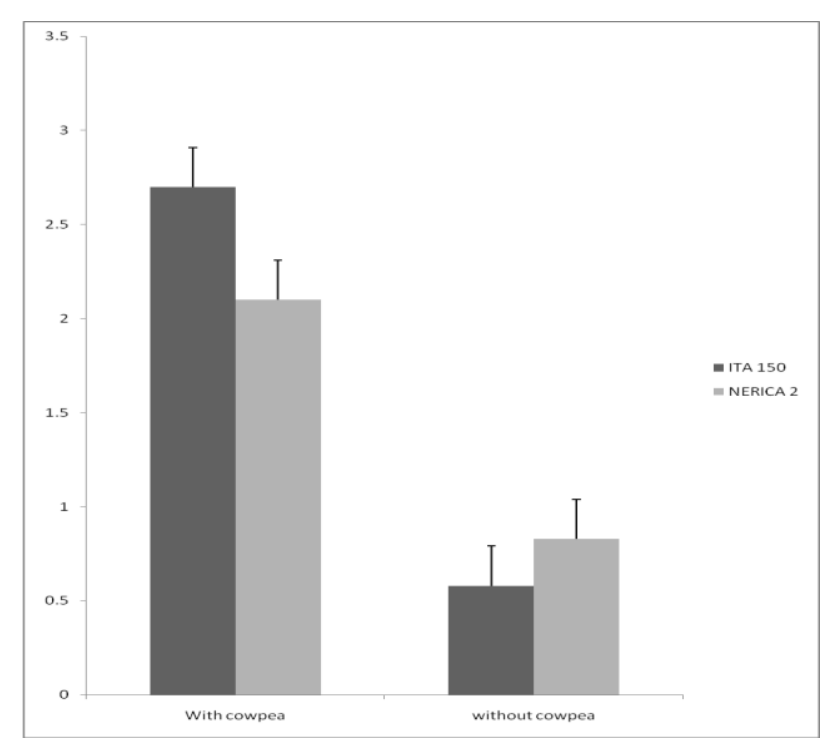

Fig 4a: interaction effects of rice $x$ cowpea on yield in 2010 


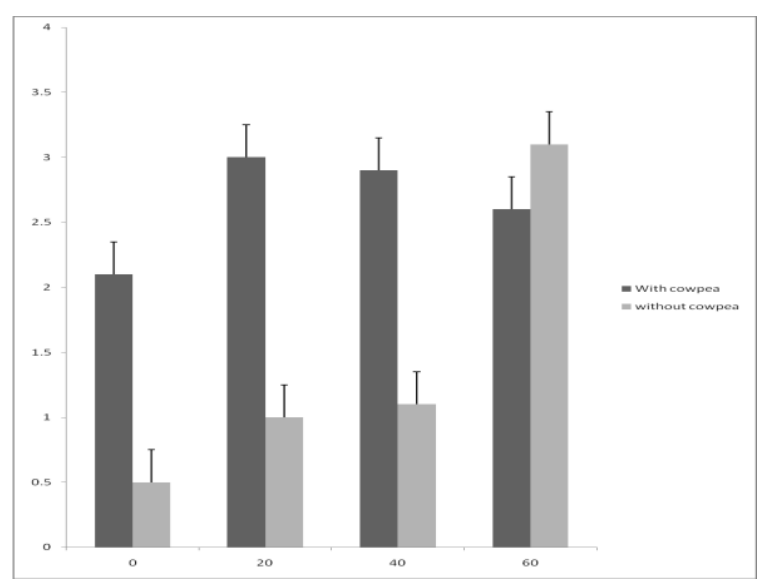

Fig 4b: Interaction effect of nitrogen rates $x$ cowpea incorporation on yield in $\mathbf{2 0 1 0}$

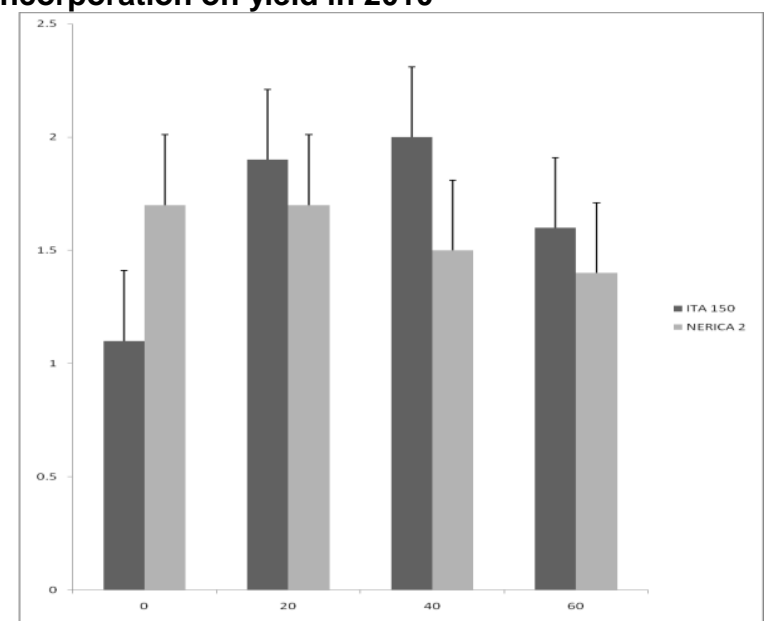

Fig 4c: Interaction effect of rice $x$ nitrogen rates on yield in 2010 DISCUSSION

This study has shown the response of the rice varieties to incorporation of cowpea residue and nitrogen application rates. The use of nitrogen has been found to result in high level of crop production. Nitrogen perhaps, is the most critical nutrient element essential for the growth and development of plants because it is easily leached and washed away as run off (Blevin et al 1996). The contribution of nitrogen has been known to be the most important nutrient in rice system and this has been known to account for $67 \%$ of the total fertilizer applied to rice (Vlek and Byrnes 1986). The influence of nitrogen rates on the yield attributes of rice showed that as the nitrogen rates increases there is an increase in the yield attributes of rice measured.
However, incorporated cowpea residue significantly had the highest 1000 grain weight and panicle length which might have translated into higher grain yield of rice. NERICA 2 produced the highest grain yield ( 2.3 and 1.7 ton $\mathrm{ha}^{-1}$ ) when compared with the yield of rice obtained from ITA 150 (1.7 and 1.5 ton $\mathrm{ha}^{-1}$ ) in both years. This could be because of its genetic potentials to partition photosynthates into kernels to produce more grain yield. The influence of legume/rice sequence and the application of nitrogen were to improve the current integrated soil fertility management practices of the farmers by incorporating it into the soil. In this study, incorporating cowpea before the sowing of rice had the best advantage by increasing rice yield In earlier research findings, advantage of cowpea residue had earlier been reported by Casky et al (1998) Okeleye et al (2009) and Okonji (2010). The incorporation of cowpea before the planting of rice in this study increased 1000 grain weight, panicle length and consequently the grain yield of rice in both years. Van Noordwisk et al (1995) reported that nitrogen from cowpea made available to a subsequent crop was estimated to be $83 \%$. This could have been the reason why cowpea plots preceding rice had the highest contribution to the yield of rice in this study. Also Okeleye et al (2002) reported that the incorporation of legume back into the soil immediately after harvest with an addition of $30 \mathrm{~kg} \mathrm{~N}$ to the succeeding rice in rotation would enhance rice yield in both rainfed upland and lowland agroecologies. Previous studies has also indicated indicated that incorporation of groundnut residues 2 weeks before rice transplanting resulted in highest benefits for growth and yield of succeeding rice (McDonagh et al., 1995). In this study it was observed that the incorporation of cowpea into the soil immediately after harvest with the addition of as little as $20 \mathrm{~kg} \mathrm{~N}^{-1}$ would enhance the yield of rice.

This study has shown that growing of NERICA rice on fields with incorporated legume residue has its inherent advantage in terms of increased rice grain yield with as low as $20 \mathrm{~kg} \mathrm{~N} \mathrm{ha}^{-1}$. It is recommended that small holder farmers can grow NERICA rice at lower rates of $\mathrm{N}$ depending on the nutrient status of the soil. The use of organic manure, green manure and most especially incorporation of residues of leguminous crops into succeeding grain crops' fields should be encouraged to bridge the gap of non availability and high cost of inorganic fertilizers with a view to obtain a sustainable and optimum crop yield. 
Agric. Biol. J. N. Am., 2011, 2(12): 1427-1436

Table 2: Mean effects of nitrogen source on yield and yield component of rice in 2009 and 2010

\begin{tabular}{|c|c|c|c|c|c|c|c|c|}
\hline \multirow[t]{2}{*}{ Nitrogen source } & \multicolumn{2}{|c|}{ Number of grains per panicle } & \multicolumn{2}{|c|}{1000 grain weight $(\mathrm{g})$} & \multicolumn{2}{|c|}{ Panicle length $(\mathrm{cm})$} & \multicolumn{2}{|c|}{ Grain yield (Ton ha) } \\
\hline & 2009 & 2010 & 2009 & 2010 & 2009 & 2010 & 2009 & 2010 \\
\hline Cowpea residue incorporated & $126.2 b$ & 101 & $42.9 a$ & 45.9 & 23.3 & $26.4 a$ & $2.5 a$ & $2.6 \mathrm{a}$ \\
\hline No Cowpea residue incorporated & $134.8 \mathrm{a}$ & 89 & $35.1 b$ & 41.7 & 23.7 & $22.4 \mathrm{~b}$ & $1.6 \mathrm{~b}$ & $1.3 b$ \\
\hline LSD (5\%) & 4.3 & ns & 3.0 & ns & ns & 1.2 & 0.2 & 0.3 \\
\hline \multicolumn{9}{|l|}{ Nitrogen rates $\left(\mathrm{ha}^{-1}\right)$} \\
\hline 0 & 121 & $87 b$ & 38.2 & 36.4 & 23.6 & $22.4 b$ & $1.6 \mathrm{~d}$ & $1.4 \mathrm{c}$ \\
\hline 20 & 129 & $94 b$ & 37.8 & 41.3 & 23.8 & $25.3 a$ & $1.8 \mathrm{c}$ & $2.0 \mathrm{~b}$ \\
\hline 40 & 127 & $106 a$ & 35.9 & 42.1 & 23.1 & $25.2 a$ & $2.0 \mathrm{~b}$ & $2.1 \mathrm{~b}$ \\
\hline 60 & 144 & $111 a$ & 44.1 & 48.3 & 23.6 & $24.9 a$ & $2.6 a$ & $2.9 a$ \\
\hline LSD (5\%) & ns & 9.5 & $\mathrm{~ns}$ & Ns & ns & 0.9 & 0.1 & 0.1 \\
\hline \multicolumn{9}{|l|}{ Rice } \\
\hline ITA 150 & 130 & 94 & 45.2 & 40.1 & 23.5 & $23.5 b$ & $1.7 \mathrm{~b}$ & $1.5 \mathrm{~b}$ \\
\hline NERICA 2 & 131 & 101 & 32.8 & 43.3 & 23.5 & $24.6 a$ & $2.3 a$ & $1.7 \mathrm{a}$ \\
\hline LSD (5\%) & ns & ns & $\mathrm{ns}$ & Ns & ns & 0.6 & 0.09 & 0.01 \\
\hline
\end{tabular}

Table 3: interaction effect of cowpea residue $\mathrm{x}$ nitrogen rates on number of grains per panicle and panicle length of rice

\begin{tabular}{|c|c|c|c|}
\hline Source & \multicolumn{2}{|c|}{ Number of grains per panicle } & Panicle length $(\mathrm{cm})$ \\
\hline Cowpea $\times$ Nitrogen rates $\left(\mathrm{ha}^{-1}\right)$ & 2009 & 2010 & 2010 \\
\hline Cowpea residue $\times 0 \mathrm{~N}$ & $126 b c$ & $93 d$ & $23.0 c$ \\
\hline Cowpea residue $\times 20 \mathrm{~N}$ & $122 \mathrm{~cd}$ & $108 \mathrm{bc}$ & $26.8 b$ \\
\hline Cowpea residue $\times 40 \mathrm{~N}$ & $114 d$ & $112 b$ & $27.6 a b$ \\
\hline Cowpea residue $\times 60 \mathrm{~N}$ & $138 b$ & $130 a$ & $28.4 a$ \\
\hline No cowpea residue $\times 0 \mathrm{~N}$ & $116 d$ & $81 \mathrm{e}$ & $21.8 d$ \\
\hline No cowpea residue $\times 20 \mathrm{~N}$ & $138 b$ & $81 e$ & $23.8 c$ \\
\hline No cowpea residue $\times 40 \mathrm{~N}$ & $135 b$ & 99cd & $22.8 c$ \\
\hline No cowpea residue $\times 60 \mathrm{~N}$ & $150 \mathrm{a}$ & $92 d$ & $21.4 d$ \\
\hline LSD (5\%) & 10.5 & 11.1 & 1.2 \\
\hline
\end{tabular}




\section{CONCLUSION AND RECOMMENDATION:}

From this study it can be concluded that the growing of rice on a field previously incorporated with legumes had an advantage over when no cowpea is used. It has also shown that NERICA 2 incorporated with cowpea and as little as $20 \mathrm{~kg} \mathrm{~N} \mathrm{ha}^{-1}$ had the best grain yield.

\section{REFERENCES}

Abifarin, A.O; Chabrolin.; Jacqot, M; Marie, R, and Modmaw, J.C (1972) (eds). Upland rice improvement in West Africa. In international Rice Research Institute, Rice Breedings. Los Banos Phillipines. pp 623-635.

Armstrong, R.D., McCosker, K. Millar, G. Kuskopf, B. Johnson, S. Walsh, K. Probert., M.E. and Standley, J. 1999. Legume and opportunity cropping systems in central Queensland. 2. Effect of legumes on following crops, Aust. J. Agric. Res. 50, pp. 925-936.

Dingkuhn M Jones MP Johnson D E Sow A. Growth and yield potential of $O$. sativa and $O$. glaberrima upland rice cultivars and their interspecific progenies. Field Crops Research. 1998; 57:57-69.

Barzejar, A.R., You Sefi, A., Daryashenas. A., 2002. The effect of addition of different amount and types of organic materials on soil physical properties and yield of wheat plant soil 247, 295-301.

Blevins, D.W., Wilkison, D. H., Kelly, B. P. and Silva, S. R. (1996). Movement of nitrate fertilizer to glacial till and runoff from a claypan soil. Journal of Environmental Qual. 25: 584 - 593.

Casky, R. J. Tarawali, S.A, Becker, M, Chikoye, O. Tian. G. and Sanginga, N. (1998). Mucuna herbeceause cover legume with potential for multiple use. Resource and Crop Management Research Monograph IITA No. 25 p 38

Christense B.T. 1986. Straw incorporation and soil organic matter in macro aggregates and particle size separates. Journal of soil science. 37:125-135.

Eneji, A. E., Yamamot, S., Honna, T., 2001. Rice growth and nutrient update as affected by livestock manure in four Japanese Soils. J plant Nutri, 124, 333-33.

Fagade, S.O. (2000). Yield gaps and productivity decline in rice production in Nigeria International Rice Communication. FAO. p15

Food and Agricultural Organization (2007). FAO Rice Market Monitor. Vol. $X$ No. 1. In http://www.fao.org/es/esc/en/index.html

Okeleye, K.A; Adeoti, A.Y.A and Tayo. T.O. (2006). Farmers participatory rice variety selection trials at ibogun Olaogun village, Ogun State Nigeria.
International Journal of Tropical Agriculture 24 (1) 57 64.

Okeleye, K.A; Oyekanmi, A.A., O.J. Ariyo and Tayo. T.O. (2002). Performance of rice varieties under upland and lowland rainfed ecologies of south western Nigeria. Asset Seriees A 2 (2) 127 - 140

Okeleye K. A., Oikeh, S. O, Aderibigbe, S. G, Okonji, C. J, Nwilene, F and Ajayi, O. (2009). Influence of Legume/rice Sequence and Nitrogen on NERICA rice in Rainfed Upland and Lowland Ecologies $f$ West Africa. The Proceedings of the International Plant Nutrition Colloquium XVI. Paper 1423. (http://repositories.cdlib.org/ipnc/xvi/1423)

Okonji.C. J, Okeleye, K. A., Oikeh, S. O., Aderibigbe, S.G., Nwilene, F ., Ajayi, O. and A. Oyekanmi (2010). Influence of Legume/rice Sequence and nitrogen on NERICA rice in Rainfed Upland and Lowland Ecologies of West Africa (Archives of Agronomy and Soil Science). In press.

Oyekanmi.A.A., Okonji. C.J., Odedina J.N., Atayese M.O. and Okeleye. K.A. (2009) Effect of poultry manure on the yield components and grain yield of upland rice varieties. International Journal of Tropical Agriculture. Vol. 27. No. 3-4 pp. 549-553

McDonagh, J.F., Toomsan, B., Limpinuntana, V. and Giller, K.E. 1995. Grain legumes and green manures as prerice crops in Northeast Thailand. I. Legume $\mathrm{N}_{2}$-fixation, production and residual nitrogen benefits to rice, Plant Soil 177 , pp. 111-126.

Pernes-Debuyser, A. Tessier, D., 2004. Soil physical properties affected by long term fertilization. Enr. J. Soil Sci. 55, 505-512

Prassad, P.V.V. Satyana rayana, V, Murty, V.R., Broote, K.J., 2002. Maximizing yield in rice groundnut cropping sequence through integrated nutrient management. Filed crop Res. 75, 9-21.

Singh, M; Singh, V.P Reddy, K.S. 2001. Effect of integrated use of fertilizer nitrone and farmyard manure or green manure on transformation of $\mathrm{N}, \mathrm{K}$ and $\mathrm{S}$ and productivity of rice colead system and vertisol. J. Indian Soc. Soil Sci. 49, 440-435.

Sanginga, N. 2003. Role of biological nitrogen fixation in legume based cropping systems; a case study of West Africa farming systems, Plant Soil 252 (2003), pp. 2539.

Sarkar, S., Rathore, T.R., Sachan, R.S. \& Guildyal, B.P. 1988. Effect of straw incorporation and burning on $\mathrm{pH}$ and organic carbon status of Tarai soils. Journal of the Indian society of soil science. 36:158-160. 
Sarkar,S., Singh, S.R., Singh R.P.2003. The effect of organic and inorganic fertilizers on soil physical condition and the productvity of a rice-wheat cropping sequence in India. J. Agric. Sci. 140,419-425

Toomsan, B., McDonagh, J.F., Limpinuntana, V. and Giller, K.E. 1995. Nitrogen fixation by groundnut and soyabean and residual nitrogen benefits to rice in farmers' fields in Northeast Thailand, Plant Soil 175, pp. 45-56.

Toomsan, B., Cadisch, G., Srichantawong, M., Thongsodsaeng, C., Giller, K.E. and Limpinuntana, V. 2000. Biological $N_{2}$ fixation and residual $N$ benefit of pre- rice leguminous crops and green manures, Netherlands J. Agric. Sci. 48, pp. 19-29.

Vlek, P.L and Byrnes, B.H. (1986). The efficacy and loss of fertilizer $\mathrm{N}$ in lowland rice. Fertilizer Research 9: 131 147.
Van Noordwijk, M Sitompul, S.M, Hairiah, K and Listyarini, E. (1995). Nitrogen supply from rotation of spatially zoned inclusion of leguminousae for sustainable maize production on an acid soil in Indonesia. 779 - 784. In plant soil interaction at low $\mathrm{pH}$, edited by R.A. Date et al Kluwer.

Whitmore, A.P., Cadisch, G., Toomsan, B., Limpinuntana, V., Van Noorwijk. M. and Purnomosidhi, P. 2000. An analysis of the economic values of novel cropping systems in N.E. Thailand and S. Sumatra, Netherlands J. Agric. Sci. 48, pp. 1055-1114.

Wijnhoud, J.D., Konboon, Y. and Lefroy, R.D.B. 2003. Nutrient budgets: sustainability assessment of rainfed lowland rice-based systems in northeast Thailand, Agric. Ecosyst. Environ. 100, pp. 119-127. 